\title{
Optimal Management of Chronic Severe Aortic Regurgitation - How to Determine Cutoff Values for Surgical Intervention? -
}

\author{
Masashi Amano, MD, PhD; Chisato Izumi, MD, PhD
}

\begin{abstract}
Aortic regurgitation $(\mathrm{AR})$ is a common valvular heart disease, but the optimal timing of surgical intervention remains controversial. In the natural history of chronic severe AR, sudden death is rare, and the annual mortality rate is comparatively low. Considering the hemodynamic features of combined volume and pressure overload and long-term compensation in patients with chronic AR, symptoms related to AR do not frequently occur. Therefore, the progression of left ventricular (LV) dysfunction is a key factor in determining the timing of surgical intervention in patients with severe chronic AR. In addition to symptoms, an ejection fraction $<50 \%$ and an LV endsystolic diameter (LVESD) $>45 \mathrm{~mm}$ are appropriate cutoff values for surgical intervention in Japanese patients, whereas LV enddiastolic diameter is not a good indicator. An LVESD index of $25 \mathrm{~mm} / \mathrm{m}^{2}$ is controversial, because adjusting for body size may cause overcorrection in Japanese patients who have a small body size compared with Westerners. Accumulation of data from the Japanese population is indispensable for establishing guidelines on optimal management of patients with chronic AR.
\end{abstract}

Key Words: Aortic valve; Left ventricular function; Surgery; Survival

A ortic regurgitation (AR) is one of the common valvular heart diseases, although its prevalence is comparatively low compared with aortic stenosis and mitral regurgitation. $\mathbf{1 , 2}^{\mathrm{A}} \mathrm{AR}$ is characterized by diastolic reflux of blood from the aorta into the left ventricle (LV), resulting in an increase in total stroke volume (SV). Acute $\mathrm{AR}$ is rare, but it induces rapid cardiac decompensation; thus, most patients require emergency surgical intervention. ${ }^{3}$ Chronic AR is generally well tolerated for a long period, and few patients show symptoms (New York Heart Association [NYHA] functional class $\geq$ III) before LV dysfunction occurs. The optimal timing of surgical intervention in asymptomatic patients with chronic severe AR remains controversial in current guidelines. ${ }^{46}$ Considering the increasing number of elderly patients and the small body size of Japanese compared with Westerners, the optimal cutoff value of ejection fraction (EF) and LV size for surgical intervention may need to be reconsidered. Here we review previous studies related to the treatment of severe chronic AR to obtain a clinical perspective on chronic AR in Japan.

\section{Hemodynamics and Natural History of Chronic AR}

In patients with chronic AR, the LV responds to chronic volume overload via a series of compensatory mechanisms, including an increase in end-diastolic volume, an increase in chamber compliance that accommodates this increase in volume without a rise in filling pressure, and hypertrophy. ${ }^{7}$ In contrast to mitral regurgitation, in which part of the SV regurgitates into the left atrium, a low-pressure chamber, $\mathrm{LV}$ afterload increases in AR, resulting from an increase in $\mathrm{SV}$ and systolic pressure. Combined volume and pressure overload is a hemodynamic feature of chronic AR (Figure 1), ${ }^{\mathbf{8}-10}$ resulting in eccentric hypertrophy and a spherical LV (Figure 2). As indicated by Laplace's law: wall stress $=p \times \mathrm{r} / 2 \mathrm{~h}(p$ : LV pressure, $r: \mathrm{LV}$ radius; $h$ : wall thickness), the increase in wall thickness is a compensatory mechanism; ${ }^{7}$ thus, a normal EF is maintained long-term, and the majority of patients with chronic AR remain asymptomatic during hemodynamic compensation., , 11 $^{-1}$ This long-term asymptomatic phase is the main feature of the natural history of chronic AR. However, a long-term increase in afterload may lead to a reduction in EF, which is initially reversible, but can become irreversible. In this natural course of chronic AR, patients are usually asymptomatic until the development of LV dysfunction, and may remain asymptomatic even with advanced LV dysfunction.

Data related to the natural history of patients with severe chronic AR are outdated. In 1991, Bonow et al reported the clinical course of 104 asymptomatic patients with a normal EF, showing that $\approx 60 \%$ of them remained asymptomatic during 11 years of follow-up, and sudden cardiac death was rare (1.9\%). ${ }^{\mathbf{2}}$ In 1995, Tornos et al prospectively investigated the natural history of 101 asymptomatic patients with severe chronic AR and normal LV systolic function. ${ }^{13}$ During a follow-up period of 4.6 years, there were no cardiac deaths, and 14 patients $(14 \%)$ required surgical intervention, including 8 for development of symptoms and 6 for LV dysfunction. Previous American

Received July 20, 2021; accepted July 20, 2021; J-STAGE Advance Publication released online August 28, 2021

Department of Cardiovascular Medicine, National Cerebral and Cardiovascular Center, Suita, Japan

Mailing address: Chisato Izumi, MD, PhD, Department of Cardiovascular Medicine, National Cerebral and Cardiovascular Center,

6-1 Kishibe-shimmachi, Suita 564-8565, Japan. E-mail: izumi-ch@ncvc.go.jp

All rights are reserved to the Japanese Circulation Society. For permissions, please e-mail: cj@j-circ.or.jp

ISSN-1346-9843 
(A)
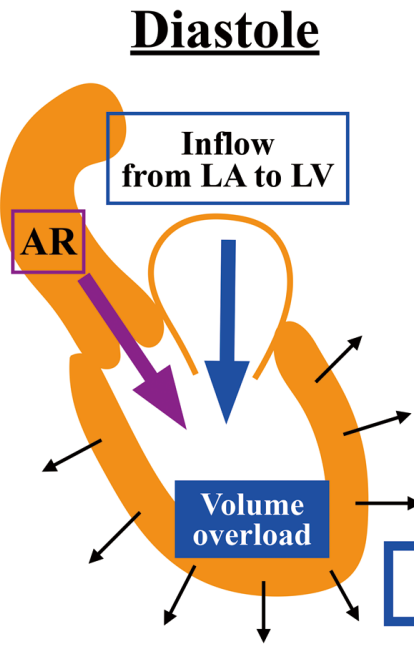

(B) $\underline{\text { Systole }}$

Figure 1. Hemodynamic features of chronic AR. (A) In diastole, inflow from the LA and regurgitant volume from the aorta pour into the LV simultaneously, resulting in volume overload. (B) In systole, systolic aortic pressure increases, which is accompanied by an increase in total SV, and LV afterload also increases. Subsequently, an increase in wall thickness occurs as a compensatory mechanism. AR, aortic regurgitation; LA, left atrium; LV, left ventricle; SV, stroke volume.

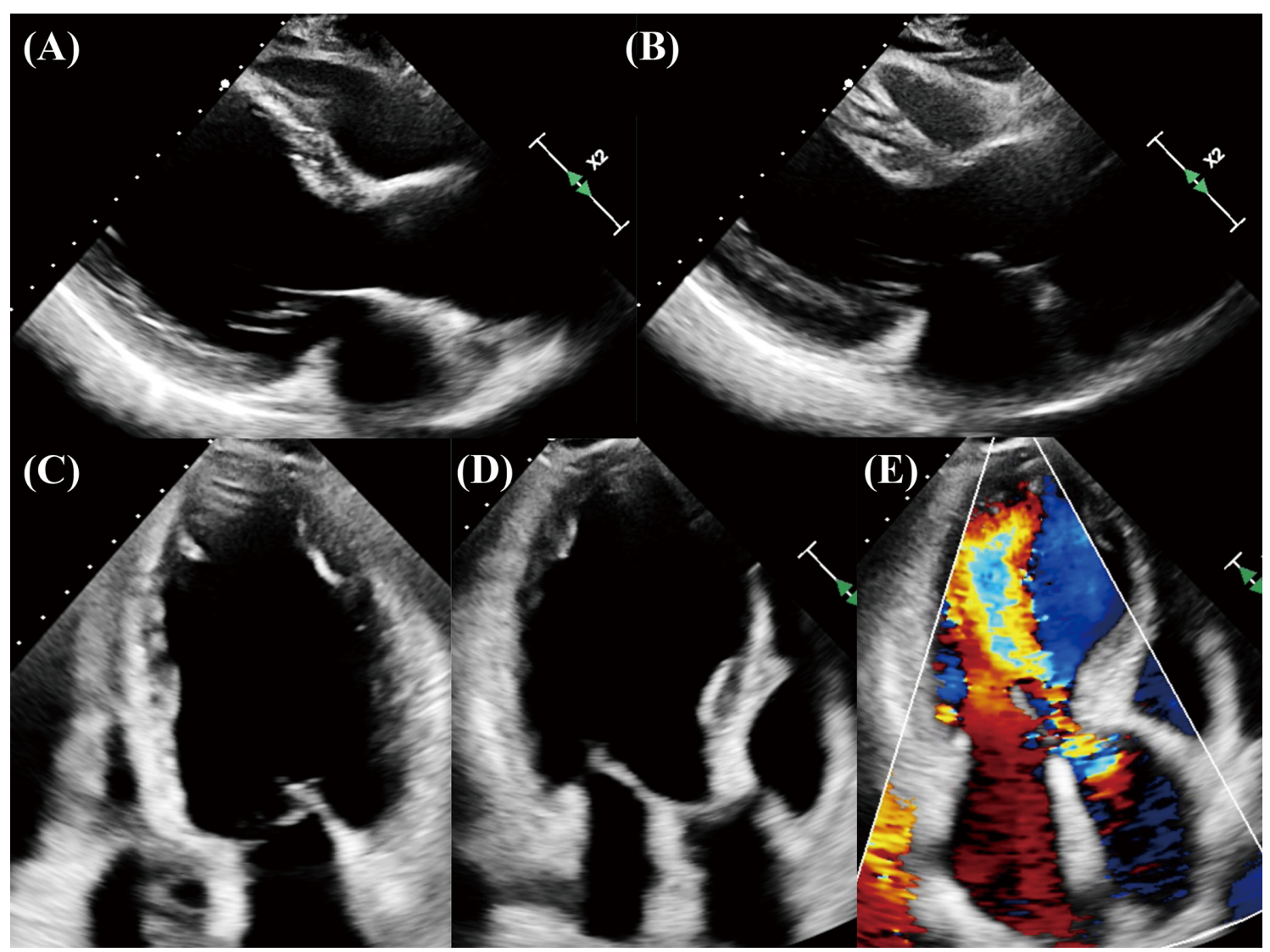

Figure 2. Typical echocardiographic images of chronic severe AR. Blood pressure on echocardiography is $138 / 39 \mathrm{mmHg}$. (A) Parasternal view in diastole (LV end-diastolic dimension $77 \mathrm{~mm}$ ). The LV shows eccentric hypertrophy. (B) Parasternal view in systole (LV endsystolic dimension $49 \mathrm{~mm}$ ). (C,D) Apical 4- and 3-chamber views in diastole. The LV is spherical. (E) Color image in apical 3-chamber view. AR flow reaches to the LV apex and the PISA radius is enlarged. AR, aortic regurgitation; LV, left ventricle/ventricular; PISA, proximal isovelocity surface area. 


\begin{tabular}{|c|c|c|c|c|c|c|c|c|}
\hline $\begin{array}{c}\text { Author } \\
\text { (year) }^{\text {Ref. }}\end{array}$ & Country & $\begin{array}{l}\text { Period of } \\
\text { study }\end{array}$ & $\begin{array}{l}\text { No. of } \\
\text { patients }\end{array}$ & $\begin{array}{l}\text { Mean } \\
\text { age }\end{array}$ & BSA & Symptoms & $\begin{array}{l}\text { Outcome } \\
\text { assessed }\end{array}$ & Findings \\
\hline $\begin{array}{l}\text { Forman et al } \\
(1980)^{35}\end{array}$ & ZAF & $1972-1978$ & 229 & NA & NA & NA & $\begin{array}{l}\text { Postoperative } \\
\text { survival }\end{array}$ & $\begin{array}{l}\text { High-risk group identified by } \\
\text { preoperative angiographic EF } \\
<50 \%\end{array}$ \\
\hline $\begin{array}{l}\text { Greves et al } \\
(1981)^{36}\end{array}$ & USA & 1973-1979 & 45 & 45 & NA & $\begin{array}{c}\text { Symptomatic } \\
49 \% \\
\text { Asymptomatic } \\
51 \%\end{array}$ & $\begin{array}{l}\text { Postoperative } \\
\text { survival }\end{array}$ & $\begin{array}{l}\text { High-risk group identified by } \\
\text { preoperative angiographic EF } \\
<45 \%\end{array}$ \\
\hline $\begin{array}{l}\text { Klodas et al } \\
(1996)^{37}\end{array}$ & USA & 1980-1989 & 219 & 54 & NA & $\begin{array}{c}\text { Symptomatic } \\
36 \% \\
\text { Asymptomatic } \\
64 \%\end{array}$ & $\begin{array}{l}\text { Postoperative } \\
\text { survival }\end{array}$ & $\begin{array}{l}\text { High-risk group identified by } \\
\text { preoperative angiographic EF } \\
<50 \%\end{array}$ \\
\hline $\begin{array}{l}\text { Tornos et al } \\
(2006)^{32}\end{array}$ & ESP & 1982-2002 & 170 & 50 & NA & $\begin{array}{c}\text { Symptomatic } \\
39 \% \\
\text { Asymptomatic } \\
61 \%\end{array}$ & $\begin{array}{l}\text { Postoperative } \\
\text { survival }\end{array}$ & $\begin{array}{l}\text { High-risk group identified } \\
\text { prospectively by preoperative } \\
\text { low EF (mean EF 42\%) }\end{array}$ \\
\hline $\begin{array}{l}\text { Zhang et al } \\
(2015)^{38}\end{array}$ & $\mathrm{CHN}$ & 2005-2011 & 105 & 50 & 1.7 & $\begin{array}{c}\text { Symptomatic } \\
38 \% \\
\text { Asymptomatic } \\
62 \%\end{array}$ & $\begin{array}{l}\text { Postoperative } \\
\text { recovery of } \\
\text { LVEDD }\end{array}$ & $\begin{array}{l}\text { Preoperative EF }>52 \% \text { may be } \\
\text { a good predictor of successful } \\
\text { recovery of dilated LVEDD } \\
\text { early after AVR }\end{array}$ \\
\hline $\begin{array}{l}\text { de Meester } \\
\text { et al }(2015)^{39}\end{array}$ & BEL & 1995-2012 & 160 & 50 & 1.9 & Asymptomatic & $\begin{array}{l}\text { Postoperative } \\
\text { survival }\end{array}$ & $\begin{array}{l}\text { No benefits of AVR for survival } \\
\text { in patients with preoperative } \\
\text { LVESD }<50 \mathrm{~mm} \text {, LVEDD } \\
<70 \mathrm{~mm} \text {, and EF }>50 \%\end{array}$ \\
\hline $\begin{array}{l}\text { Murashita et al } \\
(2017)^{40}\end{array}$ & USA & 2004-2014 & 530 & 57 & NA & $\begin{array}{c}\text { Symptomatic } \\
32 \% \\
\text { Asymptomatic } \\
68 \%\end{array}$ & $\begin{array}{l}\text { Postoperative } \\
\text { survival }\end{array}$ & $\begin{array}{l}\text { High-risk group identified by } \\
\text { preoperative EF }<60 \%\end{array}$ \\
\hline $\begin{array}{l}\text { de Meester } \\
\text { et al }(2019)^{41}\end{array}$ & BEL & 1995-2012 & 356 & 51 & NA & $\begin{array}{c}\text { Symptomatic } \\
18 \% \\
\text { Asymptomatic } \\
82 \%\end{array}$ & $\begin{array}{l}\text { Postoperative } \\
\text { survival }\end{array}$ & $\begin{array}{l}\text { Mortality rate started to } \\
\text { increase with EF }<55 \%\end{array}$ \\
\hline $\begin{array}{l}\text { Taniguchi et al } \\
(1987)^{42}\end{array}$ & JPN & 1978-1985 & 62 & 42 & NA & $\begin{array}{c}\text { Symptomatic } \\
50 \% \\
\text { Asymptomatic } \\
50 \%\end{array}$ & $\begin{array}{l}\text { Postoperative } \\
\text { survival }\end{array}$ & $\begin{array}{l}\text { High-risk group identified by } \\
\text { preoperative EF }<40 \%\end{array}$ \\
\hline $\begin{array}{l}\text { Amano et al } \\
(2016)^{43}\end{array}$ & JPN & 1995-2010 & 80 & 59 & 1.6 & NA & $\begin{array}{l}\text { Postoperative } \\
\text { cardiac death }\end{array}$ & $\begin{array}{l}\text { High-risk group identified by } \\
\text { preoperative EF }<50 \%\end{array}$ \\
\hline
\end{tabular}

AVR, aortic valve replacement; EDD, end-diastolic diameter; EF, ejection fraction; ESD, endsystolic diameter; LV, left ventricular; NA, not applicable.

College of Cardiology (ACC)/American Heart Association (AHA) guidelines in 2006 summarized the data on the natural history of chronic AR. The average mortality rate was only $0.18 \%$ per year, and the progression rate to symptoms, death, or LV dysfunction was $4.3 \%$ per year. ${ }^{14}$ Based on the low incidence of sudden death during followup, the optimal timing of surgical intervention should be determined from the perspective of postoperative long-term outcomes.

\section{Diagnosis of Severe AR}

\section{Severity of AR}

Echocardiography is a key diagnostic tool for AR, and the etiology and severity of AR should be evaluated, even when mild AR is detected. The 3 parameters of the color jet (flow convergence, vena contracta, and jet area) are widely used to assess the severity of AR, ${ }^{15}$ but there are many pitfalls in this evaluation. ${ }^{16}$ As a quantitative method, the proximal isovelocity surface area (PISA) method can be used. ${ }^{17}$ However, in clinical settings, PISA quantitation of $\mathrm{AR}$ is used less often than for mitral regurgitation, because shadowing from aortic valve thickening and calcification often prevent accurate evaluation of flow convergence in the far field. The usefulness of the 3D vena contracta area using transesophageal echocardiography (TEE) has been reported, ${ }^{18-20}$ but determining the severity of AR using echocardiography alone is often difficult. Thus, additional imaging modalities are sometimes required to confirm AR severity.

Cardiac magnetic resonance imaging (MRI) can quantify AR directly by phase-contrast velocity mapping in a plane perpendicular to the aorta. ${ }^{\mathbf{2 1 , 2 2}}$ This method measures the regurgitant volume and fraction (reverse volume/forward volume $\times 100 \%$ ), is the most validated approach, and is not affected by coexisting valvular regurgitation lesions. ${ }^{23-25}$ Aortography with the Sellers classification using a cardiac catheter is still useful for evaluating the severity of AR. When evaluating severity, especially in patients with moderate or severe AR, an integrated approach using echocardiography, cardiac MRI, and/or aortography is required in the clinical setting. 


\begin{tabular}{|c|c|c|c|c|c|c|c|c|}
\hline $\begin{array}{l}\text { Author } \\
\text { (year) }^{\text {Ref. }}\end{array}$ & Country & $\begin{array}{l}\text { Period of } \\
\text { study }\end{array}$ & $\begin{array}{l}\text { No. of } \\
\text { patients }\end{array}$ & $\begin{array}{l}\text { Mean } \\
\text { age }\end{array}$ & BSA & Symptoms & $\begin{array}{l}\text { Outcome } \\
\text { assessed }\end{array}$ & Findings \\
\hline $\begin{array}{l}\text { Gaasch et al } \\
(1983)^{45}\end{array}$ & USA & 1975-1980 & 32 & 45 & 1.9 & NA & $\begin{array}{l}\text { Postoperative } \\
\text { LV } \\
\text { enlargement }\end{array}$ & $\begin{array}{l}\text { Patients with preoperative } \\
\text { LVESD }>50 \mathrm{~mm} \text { or an LVESD } \\
\text { index of } 26 \mathrm{~mm} / \mathrm{m}^{2} \text { showed poor } \\
\text { outcomes (persistent LV } \\
\text { enlargement) }\end{array}$ \\
\hline \multirow[t]{2}{*}{$\begin{array}{l}\text { Tornos et al } \\
(2006)^{32}\end{array}$} & \multirow[t]{2}{*}{ ESP } & \multirow[t]{2}{*}{ 1982-2002 } & \multirow[t]{2}{*}{170} & \multirow[t]{2}{*}{50} & \multirow[t]{2}{*}{ NA } & $\begin{array}{c}\text { Symptomatic } \\
39 \%\end{array}$ & \multirow[t]{2}{*}{$\begin{array}{l}\text { Postoperative } \\
\text { survival }\end{array}$} & \multirow[t]{2}{*}{$\begin{array}{l}\text { Low-risk group identified by } \\
\text { preoperative LVESD of } 48 \mathrm{~mm}\end{array}$} \\
\hline & & & & & & $\begin{array}{c}\text { Asymptomatic } \\
61 \%\end{array}$ & & \\
\hline $\begin{array}{l}\text { Detaint et al } \\
(2008)^{46}\end{array}$ & USA & 1991-2003 & 93 & 58 & NA & Asymptomatic & $\begin{array}{l}\text { Cardiac } \\
\text { events }\end{array}$ & $\begin{array}{l}\text { Patients with asymptomatic } \\
\text { severe AR with an endsystolic } \\
\text { volume index } \geq 45 \mathrm{~mL} / \mathrm{m}^{2} \text { had } \\
\text { more frequent cardiac events } \\
\text { (cardiac death, congestive heart } \\
\text { failure, and new atrial fibrillation) } \\
\text { under conservative } \\
\text { management }\end{array}$ \\
\hline $\begin{array}{l}\text { Turk et al } \\
(2010)^{47}\end{array}$ & USA & 1993-2007 & 79 & 60 & NA & Asymptomatic & $\begin{array}{l}\text { Postoperative } \\
\text { survival }\end{array}$ & $\begin{array}{l}\text { Low-risk group identified by } \\
\text { preoperative LVESD }<50 \mathrm{~mm} \text {, } \\
\text { LVEDD }<70 \mathrm{~mm} \text {, and LVEF } \\
>50 \%\end{array}$ \\
\hline $\begin{array}{l}\text { de Meester } \\
\text { et al }(2015)^{39}\end{array}$ & BEL & 1995-2012 & 160 & 50 & 1.9 & Asymptomatic & $\begin{array}{l}\text { Postoperative } \\
\text { survival }\end{array}$ & $\begin{array}{l}\text { No benefits of AVR for survival } \\
\text { in patients with preoperative } \\
\text { LVESD }<50 \mathrm{~mm} \text {, LVEDD } \\
<70 \mathrm{~mm} \text {, and LVEF }>50 \%\end{array}$ \\
\hline $\begin{array}{l}\text { Saisho et al } \\
(2015)^{48}\end{array}$ & JPN & 1989-2010 & 177 & 58 & 1.6 & NA & $\begin{array}{l}\text { Postoperative } \\
\text { normal LV } \\
\text { function }\end{array}$ & $\begin{array}{l}\text { Postoperative LV function was } \\
\text { preserved in patients with } \\
\text { preoperative LVESD index } \\
\leq 26.7 \mathrm{~mm} / \mathrm{m}^{2}(\approx \mathrm{LVESD} 43 \mathrm{~mm})\end{array}$ \\
\hline $\begin{array}{l}\text { Amano et al } \\
(2016)^{43}\end{array}$ & JPN & 1995-2010 & 80 & 59 & 1.6 & NA & $\begin{array}{l}\text { Postoperative } \\
\text { survival }\end{array}$ & $\begin{array}{l}\text { Low-risk group identified by } \\
\text { preoperative LVESD } \leq 47 \mathrm{~mm} \text { or } \\
\text { an LVEF } \geq 56 \%\end{array}$ \\
\hline $\begin{array}{l}\text { Sato et al } \\
(2017)^{49}\end{array}$ & JPN & 2012-2015 & 60 & 62 & 1.7 & Asymptomatic & $\begin{array}{l}\text { MACE and } \\
\text { AVR }\end{array}$ & $\begin{array}{l}\text { In asymptomatic patients with } \\
\text { moderate to severe AR and an } \\
\text { LVESD }<50 \mathrm{~mm} \text {, endsystolic } \\
\text { volume index during exercise } \\
\text { was an independent predictor of } \\
\text { outcomes }\end{array}$ \\
\hline
\end{tabular}

$A R$, aortic regurgitation; AVR, aortic valve replacement; EDD, end-diastolic diameter; EF, ejection fraction; ESD, endsystolic diameter; LV, left ventricular; MACE, major adverse cardiovascular event; NA, not applicable.

\section{Etiology and Structural Evaluation of AR}

An etiological evaluation and structural assessment of the aortic valve and aorta should also be performed because aortic valve repair is an option for surgical intervention. Functional classification of the aortic root and valve allow for logical application of valve-sparing surgical procedures. ${ }^{26,27} 3 \mathrm{D}$ TEE as well as computed tomography is useful for measuring geometric height as an index of cusp length and effective height as an index of cusp prolapse or tethering. ${ }^{28,29}$

\section{Optimal Management of Chronic Severe AR}

Timing of Surgical Intervention in Symptomatic Patients

The prognosis of symptomatic patients with severe AR is poor, ${ }^{30-32}$ and so symptoms related to $\mathrm{AR}$ are a strong indication (Class I) for aortic valve surgery. ${ }^{46}$ In most studies related to chronic severe AR, being symptomatic is defined as NYHA class of III or IV, and patients classified as NYHA class II are asymptomatic, although Dujardin et al reported that patients with mild dyspnea (NYHA class II) display higher mortality rates compared with patients classified as NYHA class I during conservative treatment. ${ }^{31}$
In patients with minimal symptoms, an additional evaluation with exercise stress echocardiography to confirm the occurrence of symptoms and/or the presence of LV contractile reserve is useful. ${ }^{33,34}$

\section{Timing of Surgical Intervention in Asymptomatic Patients}

EF In asymptomatic patients with severe AR, LV systolic dysfunction with reduced $E F$ is a crucial indication for surgical intervention. Current guidelines from the Japanese Circulation Society (JCS), the ACC/AHA, and the European Society of Cardiology (ESC) strongly recommend (Class I) aortic valve surgery in patients with a decreased EF.46 Several investigators have identified the relationship between a low preoperative $\mathrm{EF}$ and postoperative outcomes (survival and LV function) (Table 1), 32,35 43 and the EF cutoff value for surgical indication is $50 \%$ in the current JCS and ESC guidelines. ${ }^{4,6}$ However, in the 2020 ACC/AHA guidelines, the EF cutoff value is $55 \% .{ }^{5}$ Murashita et al demonstrated that a preoperative $\mathrm{EF}<60 \%$ is related to a high all-cause mortality rate after correction for chronic severe AR. ${ }^{40} \mathrm{In}$ another study by de Meester et al, the postoperative allcause mortality rate began to increase when the preoperative $\mathrm{EF}$ was $<55 \%{ }^{41}$ However, the lower limit of EF in 


\begin{tabular}{|c|c|c|c|c|c|c|c|c|}
\hline $\begin{array}{c}\text { Author } \\
\text { (year) }^{\text {Ref. }}\end{array}$ & Country & $\begin{array}{l}\text { Period of } \\
\text { study }\end{array}$ & $\begin{array}{l}\text { No. of } \\
\text { patients }\end{array}$ & $\begin{array}{l}\text { Mean } \\
\text { age }\end{array}$ & BSA & Symptoms & $\begin{array}{l}\text { Outcome } \\
\text { assessed }\end{array}$ & Findings \\
\hline $\begin{array}{l}\text { Dujardin et al } \\
(1999)^{31}\end{array}$ & USA & 1984-1995 & 192 & 56 & 1.9 & $\begin{array}{l}\text { Symptomatic } \\
50 \% \\
\text { Asymptomatic } \\
50 \%\end{array}$ & $\begin{array}{c}\text { Survival with } \\
\text { conservative } \\
\text { treatment }\end{array}$ & $\begin{array}{l}\text { Survival of patients with a } \\
\text { baseline LVESD } \geq 25 \mathrm{~mm} / \mathrm{m}^{2} \text { was } \\
\text { lower than expected and different } \\
\text { from that of patients with an } \\
\text { LVESD }<25 \mathrm{~mm} / \mathrm{m}^{2}\end{array}$ \\
\hline $\begin{array}{l}\text { Sambola et al } \\
(2008)^{50}\end{array}$ & ESP & 1982-2005 & 147 & 51 & 1.8 & $\begin{array}{c}\text { Symptomatic } \\
76 \% \\
\text { Asymptomatic } \\
24 \%\end{array}$ & $\begin{array}{l}\text { Postoperative } \\
\text { survival }\end{array}$ & $\begin{array}{l}\text { In patients with a low BSA (1.43- } \\
\left.1.68 \mathrm{~mm} / \mathrm{m}^{2}\right) \text {, an LVESD index of } \\
25 \mathrm{~mm} / \mathrm{m}^{2} \text { should be used as a } \\
\text { cutoff value for surgery rather } \\
\text { than an LVESD of } 50 \mathrm{~mm}\end{array}$ \\
\hline $\begin{array}{l}\text { Brown et al } \\
(2009)^{51}\end{array}$ & USA & 1996-2006 & 301 & 55 & 2.0 & $\begin{array}{l}\text { Symptomatic } \\
44 \% \\
\text { Asymptomatic } \\
56 \%\end{array}$ & $\begin{array}{l}\text { Postoperative } \\
\text { survival }\end{array}$ & $\begin{array}{l}\text { Preoperative LVESD index of } \\
20 \mathrm{~mm} / \mathrm{m}^{2}(\approx \text { LVESD } 40 \mathrm{~mm}) \text { and } \\
\text { an LVEDD index of } 30 \mathrm{~mm} / \mathrm{m}^{2} \\
(\approx \text { LVEDD } 60 \mathrm{~mm}) \text { were the best } \\
\text { cutoff values for late survival after } \\
\text { AVR }\end{array}$ \\
\hline $\begin{array}{l}\text { Mentias et al } \\
(2016)^{52}\end{array}$ & USA & 2003-2010 & $\begin{array}{c}\text { 1,061 } \\
\text { (484: } \\
\text { nonsurgical) }\end{array}$ & 54 & 2.0 & $\begin{array}{c}\text { Symptomatic } \\
13 \% \\
\text { Asymptomatic } \\
87 \%\end{array}$ & $\begin{array}{c}\text { Survival with } \\
\text { conservative } \\
\text { treatment }\end{array}$ & $\begin{array}{l}\text { Nonsurgical patients with an } \\
\text { LVESD index } \leq 20 \mathrm{~mm} / \mathrm{m}^{2} \text { had } \\
\text { excellent } 5 \text {-year survival. } \\
\text { However, the risk of death } \\
\text { significantly and continuously } \\
\text { increased beyond an LVESD } \\
\text { index }>20 \mathrm{~mm} / \mathrm{m}^{2}\end{array}$ \\
\hline $\begin{array}{l}\text { Young et al } \\
(2019)^{53}\end{array}$ & USA & 2006-2017 & $\begin{array}{c}748 \\
(387: \\
\text { nonsurgical) }\end{array}$ & 58 & 2.0 & $\begin{array}{l}\text { Symptomatic } \\
46 \% \\
\text { Asymptomatic } \\
54 \%\end{array}$ & Survival & $\begin{array}{l}\text { Compared with patients with an } \\
\text { LVESD index }<20 \mathrm{~mm} / \mathrm{m}^{2} \text {, those } \\
\text { with an LVESD index of } \\
20-25 \mathrm{~mm} / \mathrm{m}^{2} \text { and } \geq 25 \mathrm{~mm} / \mathrm{m}^{2} \text { had } \\
\text { an increased risk of death }\end{array}$ \\
\hline $\begin{array}{l}\text { de Meester } \\
\text { et al }(2019)^{41}\end{array}$ & BEL & 1995-2012 & 356 & 51 & NA & $\begin{array}{c}\text { Symptomatic } \\
18 \% \\
\text { Asymptomatic } \\
82 \%\end{array}$ & $\begin{array}{l}\text { Postoperative } \\
\text { survival }\end{array}$ & $\begin{array}{l}\text { Patients with preoperative LVESD } \\
\geq 25 \mathrm{~mm} / \mathrm{m}^{2} \text { are at higher risk of } \\
\text { death or of developing HF } \\
\text { symptoms postoperatively }\end{array}$ \\
\hline $\begin{array}{l}\text { Saisho et al } \\
(2015)^{48}\end{array}$ & JPN & 1989-2010 & 177 & 58 & 1.6 & NA & $\begin{array}{l}\text { Postoperative } \\
\text { normal LV } \\
\text { function }\end{array}$ & $\begin{array}{l}\text { Postoperative LV function was } \\
\text { preserved in patients with } \\
\text { preoperative LVESD index } \\
\leq 26.7 \mathrm{~mm} / \mathrm{m}^{2}\end{array}$ \\
\hline $\begin{array}{l}\text { Maeda et al } \\
(2019)^{54}\end{array}$ & JPN & 1991-2010 & 162 & 59 & 1.6 & Asymptomatic & $\begin{array}{c}\text { Postoperative } \\
\text { survival }\end{array}$ & $\begin{array}{l}\text { Survival after AVR in patients with } \\
\text { an LVESD index }>25 \mathrm{~mm} / \mathrm{m}^{2} \text { or an } \\
\text { LVEDD }>65 \mathrm{~mm} \text { was similar to the } \\
\text { general population. Preoperative } \\
\text { LVESD index }>25 \mathrm{~mm} / \mathrm{m}^{2} \text { affected } \\
\text { survival }>10 \text { years after AVR }\end{array}$ \\
\hline
\end{tabular}

$A R$, aortic regurgitation; AVR, aortic valve replacement; EDD, end-diastolic diameter; EF, ejection fraction; ESD, endsystolic diameter; LV, left ventricular; MACE, major adverse cardiovascular event; NA, not applicable.

healthy subjects was reported as $52 \%$ in males and $54 \%$ in females. ${ }^{44}$ Thus, the EF cutoff value of $55 \%$ is within the normal EF range. In Japanese data, Amano et al ${ }^{43}$ identified a preoperative $\mathrm{EF}<50 \%$ as high-risk for postoperative cardiac death, although a preoperative EF $<56 \%$ was not. It is noteworthy that cardiac death was set as a primary endpoint in that study. The ultimate goal of aortic valve surgery in patients with severe AR is to improve cardiac outcomes; therefore, additional studies are needed to identify the optimal cutoff value to achieve favorable cardiac outcomes after aortic valve surgery.

LV Endsystolic Diameter (LVESD) and LVESD Index LVESD is also a crucial indicator for surgical intervention in asymptomatic patients with chronic severe AR. Current JCS, ACC/AHA, and ESC guidelines recommend aortic valve surgery (Class IIa) in patients with an increased LVESD. ${ }^{\mathbf{4}}$ The LVESD in patients with chronic AR reflects not only LV volume and pressure overload, but also the degree of LV systolic function. In asymptomatic patients with a normal EF, an increased LVESD indicates progres- sion of LV remodeling and subsequent LV systolic dysfunction, resulting in an increased mortality rate after aortic valve surgery. ${ }^{12,13}$ Several studies have identified a relationship between preoperatively increased LVESD or LV endsystolic volume and postoperative survival or the occurrence of cardiac events (Table 2). ${ }^{32,39,43,45-49}$ In the current ACC/ AHA and ESC guidelines, the cutoff value for LVESD that indicates surgery is $50 \mathrm{~mm} .{ }^{\mathbf{5} 6}$ In 1983 , Gaasch et al identified that patients with a preoperative LVESD index $>26 \mathrm{~mm} / \mathrm{m}^{2}$ (LVESD $>50 \mathrm{~mm}$ ) showed poor outcomes in terms of postoperative LV enlargement. ${ }^{45}$ Tornos et al reported that their early operation group (mean LVESD $48 \mathrm{~mm}$ ) demonstrated improved long-term survival compared with the conventional group with a mean LVESD of $55 \mathrm{~mm} .{ }^{32}$ Moreover, several studies have identified no benefits of aortic valve surgery on postoperative survival in patients with a preoperative LVESD $<50 \mathrm{~mm}$, an LVEDD $<70 \mathrm{~mm}$, and an LVEF $>50 \% .{ }^{39,47}$ Therefore, in the USA and Europe, an LVESD of $50 \mathrm{~mm}$ is the cutoff value for surgical intervention to improve postoperative outcomes. However, in 
Japanese studies, Saisho et al showed that postoperative $\mathrm{LV}$ function is preserved in patients with a preoperative LVESD index $\leq 26.7 \mathrm{~mm} / \mathrm{m}^{2}$ ( $\approx$ LVESD $\left.43 \mathrm{~mm}\right),{ }^{48}$ and Amano et al identified a low-risk group of patients with a preoperative LVESD $\leq 47 \mathrm{~mm}$ for postoperative survival..$^{43}$ Considering these results, the lower LVESD cutoff value of $45 \mathrm{~mm}$ for aortic valve surgery as Class IIa in the JCS guidelines may be valid for Japanese individuals who have a small body size.

Recent studies related to prognostic markers of chronic severe AR have paid much attention to the LVESD index adjusted for body size (Table 3). ${ }^{31,41,48,50-54}$ In the ACC/AHA guidelines, patients with an LVESD index $>25 \mathrm{~mm} / \mathrm{m}^{2}$ have a Class IIa indication for surgical intervention. ${ }^{\mathbf{2}}$ In 2009 , Brown et al showed that a preoperative LVESD index of $20 \mathrm{~mm} / \mathrm{m}^{2}$ was the best cutoff value for better survival late after aortic valve surgery, although $44 \%$ of their study population was symptomatic (NYHA class $\geq \mathrm{III}$ ). ${ }^{51}$ Recent big data related to survival in the USA have identified that the risk of death significantly and continuously increased beyond an LVESD index $>20 \mathrm{~mm} / \mathrm{m}^{2} .^{52,53}$ In the data, patients who did not undergo aortic valve surgery during follow-up showed a poor prognosis, but the causes of death were not specified, whether or not death was valve related. The watchful waiting strategy might not be possible in these patients. Therefore, it is difficult to conclude that further early surgical intervention confers any benefit to patients with severe chronic AR. In Europe, Sambola et al reported that an LVESD index of $25 \mathrm{~mm} / \mathrm{m}^{2}$ should be used as a cutoff value for surgery rather than an LVESD of $50 \mathrm{~mm}$ in patients with a small body surface area (1.43$\left.1.68 \mathrm{~mm} / \mathrm{m}^{2}\right) .{ }^{50}$ Their data is reflected to the ESC guidelines in 2017, in which the annotation was added that a cutoff LVESD index value of $25 \mathrm{~mm} / \mathrm{m}^{2}$ appears to be more appropriate in patients with a small body size. ${ }^{6}$ In 2019 , de Meester et al confirmed that patients with a preoperative LVESD index $\geq 25 \mathrm{~mm} / \mathrm{m}^{2}$ are at a higher risk of death or of developing HF symptoms postoperatively. ${ }^{41}$ In the USA and Europe, where average body surface area is $1.9-2.0 \mathrm{~m}^{2}$, an LVESD index $\geq 25 \mathrm{~mm} / \mathrm{m}^{2}$ may be an appropriate cutoff value, especially in patients with a small body size. Conversely, in Asian countries, including Japan, where average body surface area is $1.6-1.7 \mathrm{~m}^{2}$, using LVESD adjusted by body surface area as an optimal cutoff value for surgical intervention should be considered carefully because of LVESD overcorrection. ${ }^{38,43,48,54}$ Saisho et al reported that an LVESD index of $25 \mathrm{~mm} / \mathrm{m}^{2}$ was not an appropriate cutoff value for death, freedom from cardiac death, or rehospitalization for $\mathrm{HF}$ in the long term after surgical intervention, although postoperative LV function was preserved in patients with a preoperative LVESD index $\leq 26.7 \mathrm{~mm} / \mathrm{m}^{2} .48$ Maeda et al also demonstrated that postoperative survival between patients with an LVESD index $\leq 25 \mathrm{~mm} / \mathrm{m}^{2}$ and an LVESD index $>25 \mathrm{~mm} / \mathrm{m}^{2}$ was not different, and survival in both groups was not statistically different from the general population, although a preoperative LVESD index $>25 \mathrm{~mm} / \mathrm{m}^{2}$ affected survival $>10$ years after aortic valve surgery in the limited population who could be followed up for $>10$ years after aortic valve surgery. ${ }^{54}$ More data are needed to determine the threshold values of LV systolic diameter for predicting optimal postoperative outcomes, especially for the Japanese population.

LV End-Diastolic Diameter Current ACC/AHA and JCS guidelines provide a weak recommendation (Class
IIb) for aortic valve surgery in patients with enlarged LVEDD $(65 \mathrm{~mm}) ., 5$ There is insufficient evidence to conclude an appropriate cutoff value for surgical intervention based on LVEDD. ${ }^{\mathbf{5 1 , 5 5}}$ Recent data conclude that LVEDD is not related to postoperative outcomes. ${ }^{41,43}$ LVEDD is a marker of the severity of LV volume overload in patients with chronic AR, but it does not reflect the increase in afterload and LV systolic dysfunction. Therefore, LVEDD is inferior to LVESD as a prognostic marker to decide the optimal timing of surgical intervention. Moreover, measurement error in LVEDD occurs easily compared with LVESD, especially in patients with severe AR and a spherical LV ${ }^{\mathbf{5 6}}$ Therefore, in the clinical setting, LVESD is more useful as an indication for surgery in patients with chronic severe AR than LVEDD.

\section{Surgical Indication and Medical Therapy in Patients With Severe LV Dysfunction and Postoperative Follow-up}

As severe chronic AR is characterized by a long asymptomatic period, patients sometimes exhibit LV dysfunction at the initial diagnosis. Postoperative survival and the likelihood of residual LV dysfunction are lower in patients with severe LV dysfunction than in those with mildly reduced or normal LV function. ${ }^{\mathbf{3 2 , 5 7 , 5 8}}$ However, the benefits of surgical intervention have been identified, even in patients with severe LV dysfunction. ${ }^{58}$ Surgical intervention followed by medical treatment is a better treatment option than long-term medical therapy alone.

Originally, the goal of medical therapy in patients with chronic severe AR was to reduce systolic hypertension and LV wall stress to improve LV function. ${ }^{59,60}$ In inoperable patients with concomitant diseases, angiotensin-converting enzyme inhibitors/angiotensin II receptor blockers are preferable because relief of symptoms is sometimes achieved or the improvement in LV dysfunction may lead to operable conditions. ${ }^{61}$ Regarding $\beta$-blockers, a reduction in heart rate induces an increase in SV and systolic hypertension, as well as worsening of AR due to prolongation of diastole. Thus, the effectiveness of $\beta$-blockers in patients without an indication for surgical intervention has not been established. However, previous reports showed that $\beta$-blockers were effective in patients with severe AR and LV dysfunction. ${ }^{62,63}$

In terms of the postoperative course of patients with severe chronic AR and LV dysfunction, previous studies suggest that improvements in LV function after aortic valve surgery are achieved by an early reduction in volume overload and late remodeling. ${ }^{64} \mathbf{6 6}$ In 1988, Bonow et al evaluated the postoperative improvement in EF and identified that $59 \%$ of patients with preoperative LV dysfunction had not achieved postoperative normalization of EF 6-8 months after aortic valve surgery. ${ }^{65}$ In 2011 , however, Sénéchal et al reported that $82 \%$ of patients showed positive early LV remodeling, even 1 week after aortic valve surgery, ${ }^{66}$ as surgical techniques and postoperative outcomes have improved compared with those in the 1980s. ${ }^{67}$ More recently, Amano et al showed that LV function improved after aortic valve surgery in Japanese patients with severe AR and impaired EF, and EF was $>50 \%$ in most patients 1 year after surgery. ${ }^{43}$ Saisho et al also reported Japanese data on LV recovery immediately after, 1 year after, and late after aortic valve surgery. ${ }^{48}$ 
Therefore, even in patients with severe chronic AR and severe LV dysfunction, surgical intervention should be considered concomitant with substantial medical therapy. A preoperative evaluation of the degree of cardiac damage with multimodality imaging, including cardiac MRI, may provide important information on postoperative management.

\section{Conclusions}

Many patients with chronic severe AR become symptomatic for the first time after progression of $\mathrm{LV}$ dysfunction. In the current JCS guidelines, an EF $<50 \%$ and LVESD $>45 \mathrm{~mm}$ are Class I or IIa recommendations for surgical intervention. Moreover, LVEDD $>65 \mathrm{~mm}$ and an LVESD index $>25 \mathrm{~mm} / \mathrm{m}^{2}$ are Class IIb recommendations. Accumulation of data from among the Japanese population is indispensable for establishing guidelines on optimal management of patients with chronic AR.

\section{Disclosures}

C.I. is a member of Circulation Journal's Editorial Team. M.A. has no conflicts of interest.

\section{References}

1. Singh JP, Evans JC, Levy D, Larson MG, Freed LA, Fuller DL, et al. Prevalence and clinical determinants of mitral, tricuspid, and aortic regurgitation (the Framingham Heart Study). Am J Cardiol 1999; 83: 897-902.

2. Iung B, Delgado V, Rosenhek R, Price S, Prendergast B, Wendler $\mathrm{O}$, et al. Contemporary prese ntation and management of valvular heart disease: The EURObservational Research Programme Valvular Heart Disease II Survey. Circulation 2019; 140: $1156-1169$.

3. Cohn LH, Birjiniuk V. Therapy of acute aortic regurgitation. Cardiol Clin 1991; 9: 339-352.

4. Izumi C, Eishi K, Ashihara K, Arita T, Otsuji Y, Kunihara T, et al; on behalf of the Japanese Circulation Society Joint Working Group. JCS/JSCS/JATS/JSVS 2020 guidelines on the management of valvular heart disease. Circ J 2020; 84: 20372119.

5. Otto CM, Nishimura RA, Bonow RO, Carabello BA, Erwin JP 3rd, Gentile F, et al. 2020 ACC/AHA guideline for the management of patients with valvular heart disease: A report of the American College of Cardiology/American Heart Association Joint Committee on Clinical Practice Guidelines. Circulation 2021; 143: e72-e227.

6. Baumgartner H, Falk V, Bax JJ, De Bonis M, Hamm C, Holm PJ, et al. $2017 \mathrm{ESC} / \mathrm{EACTS}$ guidelines for the management of valvular heart disease. Eur Heart J 2017; 38: 2739-2791.

7. Otto CM, Bonow RO. Valvular heart disease: A companion to Braunwald's heart disease. In: Tornos P, Evangelista A, Rich S, editors. Aortic regurgitation, 4th edn. Philadelphia: Elsevier Saunders, 2014; $163-178$.

8. Carabello BA. Aortic regurgitation: A lesion with similarities to both aortic stenosis and mitral regurgitation. Circulation 1990; 82: $1051-1053$.

9. Ross J Jr. Afterload mismatch in aortic and mitral valve disease: Implications for surgical therapy. J Am Coll Cardiol 1985; 5: $811-826$.

10. Borow KM. Surgical outcome in chronic aortic regurgitation: A physiologic framework for assessing preoperative predictors. $J$ Am Coll Cardiol 1987; 10: 1165-1170.

11. Ricci DR. Afterload mismatch and preload reserve in chronic aortic regurgitation. Circulation 1982; 66: 826-834.

12. Bonow RO, Lakatos E, Maron BJ, Epstein SE. Serial long-term assessment of the natural history of asymptomatic patients with chronic aortic regurgitation and normal left ventricular systolic function. Circulation 1991; 84: 1625-1635.

13. Tornos MP, Olona M, Permanyer-Miralda G, Herrejon MP, Camprecios M, Evangelista A, et al. Clinical outcome of severe asymptomatic chronic aortic regurgitation: A long-term prospective follow-up study. Am Heart J 1995; 130: 333-339.

14. Bonow RO, Carabello BA, Chatterjee K, de Leon AC Jr, Faxon DP, Freed MD, et al. ACC/AHA 2006 guidelines for the man- agement of patients with valvular heart disease: A report of the American College of Cardiology/American Heart Association Task Force on Practice Guidelines (Writing Committee to Revise the 1998 Guidelines for the Management of Patients with Valvular Heart Disease) Developed in Collaboration with the Society of Cardiovascular Anesthesiologists endorsed by the Society for Cardiovascular Angiography and Interventions and the Society of Thoracic Surgeons. J Am Coll Cardiol 2006; 48: e1-e148.

15. Zoghbi WA, Adams D, Bonow RO, Enriquez-Sarano M, Foster $\mathrm{E}$, Grayburn PA, et al. Recommendations for noninvasive evaluation of native valvular regurgitation: A report from the American Society of Echocardiography developed in collaboration with the Society for Cardiovascular Magnetic Resonance. J Am Soc Echocardiogr 2017; 30: 303-371.

16. Willett DL, Hall SA, Jessen ME, Wait MA, Grayburn PA. Assessment of aortic regurgitation by transesophageal color Doppler imaging of the vena contracta: Validation against an intraoperative aortic flow probe. J Am Coll Cardiol 2001; 37: $1450-1455$.

17. Tribouilloy CM, Enriquez-Sarano M, Fett SL, Bailey KR, Seward JB, Tajik AJ. Application of the proximal flow convergence method to calculate the effective regurgitant orifice area in aortic regurgitation. J Am Coll Cardiol 1998; 32: 1032-1039.

18. Nozaki S, Mizushige K, Taminato T, Obayashi N, Matsuo H. New index for grading the severity of aortic regurgitation based on the cross-sectional area of vena contracta measured by color Doppler flow mapping. Circ J 2003; 67: 243-247.

19. Fang L, Hsiung MC, Miller AP, Nanda NC, Yin WH, Young MS, et al. Assessment of aortic regurgitation by live three-dimensional transthoracic echocardiographic measurements of vena contracta area: Usefulness and validation. Echocardiography 2005; 22: 775-781.

20. Sato H, Ohta T, Hiroe K, Okada S, Shimizu K, Murakami R, et al. Severity of aortic regurgitation assessed by area of vena contracta: A clinical two-dimensional and three-dimensional color Doppler imaging study. Cardiovasc Ultrasound 2015; 13: 24.

21. Chatzimavroudis GP, Oshinski JN, Franch RH, Pettigrew RI, Walker PG, Yoganathan AP. Quantification of the aortic regurgitant volume with magnetic resonance phase velocity mapping: A clinical investigation of the importance of imaging slice location. J Heart Valve Dis 1998; 7: 94-101.

22. Chatzimavroudis GP, Walker PG, Oshinski JN, Franch RH, Pettigrew RI, Yoganathan AP. Slice location dependence of aortic regurgitation measurements with MR phase velocity mapping. Magn Reson Med 1997; 37: 545-551.

23. Dulce MC, Mostbeck GH, O'Sullivan M, Cheitlin M, Caputo GR, Higgins CB. Severity of aortic regurgitation: interstudy reproducibility of measurements with velocity-encoded cine MR imaging. Radiology 1992; 185: 235-240.

24. Honda N, Machida K, Hashimoto M, Mamiya T, Takahashi T, Kamano T, et al. Aortic regurgitation: quantitation with MR imaging velocity mapping. Radiology 1993; 186: 189-194.

25. Ley S, Eichhorn J, Ley-Zaporozhan J, Ulmer H, Schenk JP, Kauczor HU, et al. Evaluation of aortic regurgitation in congenital heart disease: value of MR imaging in comparison to echocardiography. Pediatr Radiol 2007; 37: 426-436.

26. El Khoury G, Glineur D, Rubay J, Verhelst R, d'Acoz Yd, Poncelet $\mathrm{A}$, et al. Functional classification of aortic root/valve abnormalities and their correlation with etiologies and surgical procedures. Curr Opin Cardiol 2005; 20: 115-121.

27. Boodhwani M, de Kerchove L, Glineur D, Poncelet A, Rubay J, Astarci P, et al. Repair-oriented classification of aortic insufficiency: Impact on surgical techniques and clinical outcomes. $J$ Thorac Cardiovasc Surg 2009; 137: 286-294.

28. Schäfers HJ, Bierbach B, Aicher D. A new approach to the assessment of aortic cusp geometry. J Thorac Cardiovasc Surg 2006; 132: 436-438.

29. Komiya T, Shimamoto T, Nonaka M, Matsuo T. Is small cusp size a limitation for aortic valve repair? Eur J Cardiothorac Surg 2019; 56: 497-502.

30. Klodas E, Enriquez-Sarano M, Tajik AJ, Mullany CJ, Bailey KR, Seward JB. Optimizing timing of surgical correction in patients with severe aortic regurgitation: Role of symptoms. J Am Coll Cardiol 1997; 30: 746-752.

31. Dujardin KS, Enriquez-Sarano M, Schaff HV, Bailey KR, Seward JB, Tajik AJ. Mortality and morbidity of aortic regurgitation in clinical practice: A long-term follow-up study. Circulation 1999; 99: 1851-1857.

32. Tornos P, Sambola A, Permanyer-Miralda G, Evangelista A, Gomez Z, Soler-Soler J. Long-term outcome of surgically treated 
aortic regurgitation: Influence of guideline adherence toward early surgery. J Am Coll Cardiol 2006; 47: 1012-1017.

33. Park SJ, Enriquez-Sarano M, Song JE, Lee YJ, Ha MR, Chang SA, et al. Contractile reserve determined on exercise echocardiography in patients with severe aortic regurgitation. Circ $J$ 2013; 77: 2390-2398.

34. Wahi S, Haluska B, Pasquet A, Case C, Rimmerman CM, Marwick $\mathrm{TH}$. Exercise echocardiography predicts development of left ventricular dysfunction in medically and surgically treated patients with asymptomatic severe aortic regurgitation. Heart 2000; 84: 606-614.

35. Forman R, Firth BG, Barnard MS. Prognostic significance of preoperative left ventricular ejection fraction and valve lesion in patients with aortic valve replacement. Am J Cardiol 1980; 45: $1120-1125$.

36. Greves J, Rahimtoola SH, McAnulty JH, DeMots H, Clark DG, Greenberg B, et al. Preoperative criteria predictive of late survival following valve replacement for severe aortic regurgitation. Am Heart J 1981; 101: 300-308.

37. Klodas E, Enriquez-Sarano M, Tajik AJ, Mullany CJ, Bailey KR, Seward JB. Aortic regurgitation complicated by extreme left ventricular dilation: Long-term outcome after surgical correction. J Am Coll Cardiol 1996; 27: 670-677.

38. Zhang Z, Yang J, Yu Y, Huang H, Ye W, Yan W, et al. Preoperative ejection fraction determines early recovery of left ventricular end-diastolic dimension after aortic valve replacement for chronic severe aortic regurgitation. J Surg Res 2015; 196: $49-55$.

39. de Meester C, Gerber BL, Vancraeynest D, Pouleur AC, Noirhomme $\mathrm{P}$, Pasquet A, et al. Early surgical intervention versus watchful waiting and outcomes for asymptomatic severe aortic regurgitation. J Thorac Cardiovasc Surg 2015; 150: $1100-1108$

40. Murashita T, Schaff HV, Suri RM, Daly RC, Li Z, Dearani JA, et al. Impact of left ventricular systolic function on outcome of correction of chronic severe aortic valve regurgitation: Implications for timing of surgical intervention. Ann Thorac Surg 2017; 103: $1222-1228$.

41. de Meester C, Gerber BL, Vancraeynest D, Pouleur AC, Noirhomme P, Pasquet A, et al. Do guideline-based indications result in an outcome penalty for patients with severe aortic regurgitation? JACC Cardiovasc Imaging 2019; 12: 2126-2138.

42. Taniguchi K, Nakano S, Hirose H, Matsuda H, Shirakura R, Sakai K, et al. Preoperative left ventricular function: Minimal requirement for successful late results of valve replacement for aortic regurgitation. J Am Coll Cardiol 1987; 10: 510-518.

43. Amano M, Izumi C, Imamura S, Onishi N, Sakamoto J, Tamaki $\mathrm{Y}$, et al. Pre- and postoperative predictors of long-term prognosis after aortic valve replacement for severe chronic aortic regurgitation. Circ J 2016; 80: 2460-2467.

44. Lang RM, Badano LP, Mor-Avi V, Afilalo J, Armstrong A, Ernande L, et al. Recommendations for cardiac chamber quantification by echocardiography in adults: An update from the American Society of Echocardiography and the European Association of Cardiovascular Imaging. J Am Soc Echocardiogr 2015; 28: $1-39 . e 14$

45. Gaasch WH, Carroll JD, Levine HJ, Criscitiello MG. Chronic aortic regurgitation: Prognostic value of left ventricular endsystolic dimension and end-diastolic radius/thickness ratio. $\mathrm{J} \mathrm{Am}$ Coll Cardiol 1983; 1: 775-782.

46. Detaint D, Messika-Zeitoun D, Maalouf J, Tribouilloy C, Mahoney DW, Tajik AJ, et al. Quantitative echocardiographic determinants of clinical outcome in asymptomatic patients with aortic regurgitation: A prospective study. JACC Cardiovasc Imaging 2008; 1: 1-11.

47. Turk R, Varadarajan P, Kamath A, Sampat U, Khandhar S, Patel R, et al. Survival benefit of aortic valve replacement in older patients with asymptomatic chronic severe aortic regurgitation. Ann Thorac Surg 2010; 89: 731-737.

48. Saisho H, Arinaga K, Kikusaki S, Hirata Y, Wada K, Kakuma $\mathrm{T}$, et al. Long term results and predictors of left ventricular function recovery after aortic valve replacement for chronic aortic regurgitation. Ann Thorac Cardiovasc Surg 2015; 21: 388-395.

49. Sato Y, Izumo M, Suzuki K, Kou S, Yoneyama K, Tsukahara
M, et al. Prognostic value of exercise left ventricular end-systolic volume index in patients with asymptomatic aortic regurgitation: An exercise echocardiography study. $J$ Echocardiogr 2017; 15: $70-78$.

50. Sambola A, Tornos P, Ferreira-Gonzalez I, Evangelista A. Prognostic value of preoperative indexed end-systolic left ventricle diameter in the outcome after surgery in patients with chronic aortic regurgitation. Am Heart J 2008; 155: 1114-1120.

51. Brown ML, Schaff HV, Suri RM, Li Z, Sundt TM, Dearani JA, et al. Indexed left ventricular dimensions best predict survival after aortic valve replacement in patients with aortic valve regurgitation. Ann Thorac Surg 2009; 87: 1170-1175; discussion $1175-1176$

52. Mentias A, Feng K, Alashi A, Rodriguez LL, Gillinov AM, Johnston DR, et al. Long-term outcomes in patients with aortic regurgitation and preserved left ventricular ejection fraction. $J$ Am Coll Cardiol 2016; 68: 2144-2153.

53. Yang LT, Michelena HI, Scott CG, Enriquez-Sarano M, Pislaru $\mathrm{SV}$, Schaff HV, et al. Outcomes in chronic hemodynamically significant aortic regurgitation and limitations of current guidelines. J Am Coll Cardiol 2019; 73: 1741-1752.

54. Maeda S, Taniguchi K, Toda K, Funatsu T, Kondoh H, Yokota $\mathrm{T}$, et al. Outcomes after aortic valve replacement for asymptomatic severe aortic regurgitation and normal ejection fraction. Semin Thorac Cardiovasc Surg 2019; 31: 763-770.

55. Wang Y, Jiang W, Liu J, Li G, Liu Y, Hu X, et al. Early surgery versus conventional treatment for asymptomatic severe aortic regurgitation with normal ejection fraction and left ventricular dilatation. Eur J Cardiothorac Surg 2017; 52: 118-124.

56. Dujardin KS, Enriquez-Sarano M, Rossi A, Bailey KR, Seward JB. Echocardiographic assessment of left ventricular remodeling: Are left ventricular diameters suitable tools? J Am Coll Cardiol 1997; 30: 1534-1541.

57. Bonow RO, Nikas D, Elefteriades JA. Valve replacement for regurgitant lesions of the aortic or mitral valve in advanced left ventricular dysfunction. Cardiol Clin 1995; 13: 73-83, 85.

58. Chaliki HP, Mohty D, Avierinos JF, Scott CG, Schaff HV, Tajik $\mathrm{AJ}$, et al. Outcomes after aortic valve replacement in patients with severe aortic regurgitation and markedly reduced left ventricular function. Circulation 2002; 106: 2687-2693.

59. Levine HJ, Gaasch WH. Vasoactive drugs in chronic regurgitant lesions of the mitral and aortic valves. J Am Coll Cardiol 1996; 28: $1083-1091$.

60. Grayburn PA. Vasodilator therapy for chronic aortic and mitral regurgitation. Am J Med Sci 2000; 320: 202-208.

61. Elder DH, Wei L, Szwejkowski BR, Libianto R, Nadir A, Pauriah $\mathrm{M}$, et al. The impact of renin-angiotensin-aldosterone system blockade on heart failure outcomes and mortality in patients identified to have aortic regurgitation: A large population cohort study. J Am Coll Cardiol 2011; 58: 2084-2091.

62. Zendaoui A, Lachance D, Roussel E, Couet J, Arsenault M. Usefulness of carvedilol in the treatment of chronic aortic valve regurgitation. Circ Heart Fail 2011; 4: 207-213.

63. Sampat U, Varadarajan P, Turk R, Kamath A, Khandhar S, Pai RG. Effect of beta-blocker therapy on survival in patients with severe aortic regurgitation results from a cohort of 756 patients. $J$ Am Coll Cardiol 2009; 54: 452-457.

64. Scognamiglio R, Fasoli G, Dalla Volta S. Progression of myocardial dysfunction in asymptomatic patients with severe aortic insufficiency. Clin Cardiol 1986; 9: 151-156.

65. Bonow RO, Dodd JT, Maron BJ, O'Gara PT, White GG, McIntosh CL, et al. Long-term serial changes in left ventricular function and reversal of ventricular dilatation after valve replacement for chronic aortic regurgitation. Circulation 1988; 78: $1108-1120$.

66. Sénéchal M, Bernier M, Dagenais F, Dubois M, Dubois-Sénéchal IN, Voisine P. Usefulness of preoperative stroke volume as strong predictor of left ventricular remodeling and outcomes after aortic valve replacement in patients with severe pure aortic regurgitation. Am J Cardiol 2011; 108: 1008-1013.

67. Bhudia SK, McCarthy PM, Kumpati GS, Helou J, Hoercher KJ, Rajeswaran J, et al. Improved outcomes after aortic valve surgery for chronic aortic regurgitation with severe left ventricular dysfunction. J Am Coll Cardiol 2007; 49: 1465-1471. 